\title{
TEMPORAL VARIATION OF PAHS IN SOILS FROM THE BIOBÍO REGION: CENTRAL SOUTHERN CHILE
}

\author{
ROBERTO QUIROZ ${ }^{1,2 *}$, PETER POPP ${ }^{3}$, RICARDO BARRA ${ }^{1}$ \\ ${ }^{1}$ Center for Patagonian Ecosystems Research (CIEP), Coyhaique, Chile \\ ${ }^{2}$ Aquatic Systems Research Unit, EULA-Chile Environmental Sciences Centre, University of Concepción, Concepción, Chile \\ ${ }^{3}$ Helmholtz Centre for Environmental Research - UFZ, Department of Analytical Chemistry, Leipzig, Germany
}

(Received: December 10, 2010 - Accepted: March 9, 2011)

\begin{abstract}
In this short communication we describe the temporal variation of PAHs fingerprints and burden in surface soils from coastal and central valley sites in South Central Chile, with different anthropogenic influence. PAHs were extracted with accelerated solvent extraction and measured by HPLC with fluorescence detection. Levels of $\sum 15$ PAHs were relatively low in both sites ranging between 190 to $3396 \mathrm{ng} \mathrm{g}^{-1}$ TOC of soil, However, the fingerprints were different in both sites an increment in the total concentrations was observed $(\mathrm{p}<0.001)$ in summer compared to winter periods (May 2001 and January 2002). These results suggest a temporal change in the total burden of PAHs and that the sources are related to biomass and coal combustion.
\end{abstract}

Keyword: PAHs, Soil. Temporal variation, Pollution, Chile

\section{INTRODUCTION}

Polycyclic aromatic hydrocarbons (PAHs) are ubiquitous in the environment. The origins are mainly from incomplete combustion both from natural and anthropogenic sources[1]. Once PAHs are emitted into the atmosphere, they can be redistributed between the gas and particle phases, and are subsequently deposited to the terrestrial environment through dry or wet deposition.

Soils are a primary sink for contaminants due to their large capacity for retaining hydrophobic chemicals [2-4]. The accumulation of PAHs in soil is a result of an increment of the deposition over the degradation factors.

The increment or decrease of PAHs levels in soil results from differences between degradation and loss processes and inputs from natural or anthropogenic sources such as atmospheric deposition. Therefore, the temporal study of PAHs burden in soils could be an indicator of the pollution status of the soil compartment.In Chile only the studies of Barra et al [5] and Henriquez et [6] described PAHs levels in soils samples.

The study focuses on the evaluation of temporal variation of 15 USEPA PAHs in forest soils of two sites with different anthropogenic influence and sources. These results are complementary to those described by Barra et al., [5].

\section{EXPERIMENTAL}

\section{Sampling sites}

Lleulleu site is located in coast zone with a low anthropogenic influence with land use mainly forestry and agriculture.

Cholguan site is located in the Central Valley zone with an industrial setting (sawmill and wood-panel production). The land use is mainly forestry.

Sampling procedure

In both sampling sites soils were taken from the top $10 \mathrm{~cm}$ with a small metallic shovel. Two replicas of five points distributed on the corner of a square matrix of $100 \times 100 \mathrm{~m}$ were considered for the soil sampling, in addition the central point of the square were also sampled. Samples were stored in aluminum foil and then covered in plastic hermetic bags until analysis.

\section{Analytical procedures}

The extraction methodology was based in Quiroz et al., [7]. Soil samples were mixed with anhydrous sodium sulfate, and then extracted with Accelerated Solvent Extraction with acetone:cyclohexane $(1: 1)$ at $150^{\circ} \mathrm{C}, 14 \mathrm{MPa}$ for 5 minutes (three times). Extracts were combined and concentrated to $5 \mathrm{ml}$.

For the analysis of PAHs compounds $2 \mathrm{ml}$ of the above extracts were concentrated to $0.2 \mathrm{ml}$ and then cleaned-up in a Florisil column $(10 \mathrm{~mm}$ i.d., $3 \mathrm{~g}$ Florisil). Quantitation was performed by HPLC with fluorescence detector for PAHs

PAHs analysis was performed in $200 \mu 1$ of the above extracts, concentrated to dryness and resuspended in $200 \mu \mathrm{L}$ of acetonitrile, the homogenization was performed by sonication $(5 \mathrm{~min})$. In this case the analysis was performed with an HPLC HP1050 with fluorescence programmable detector using a chromatographic column LiChroCART 250-3, Lichrospher PAH $(5 \mu \mathrm{m})$ at $20^{\circ} \mathrm{C}$ temperature. Mobile phase was acetonitrile:water $(50 \% \mathrm{~V}: \mathrm{V})$, increasing the acetonitrile proportion to $60 \%(0-3 \mathrm{~min})$ and $100 \%(3-14 \mathrm{~min})$. This proportion was maintained constant until $24 \mathrm{~min}$.

\section{Quality control /Assurance}

The PAH calibration mix (10mg of each compound per ml acetonitrile) was supplied by Supelco. HPLC grade water and acetonitrile were supplied by Baker.

Procedural blanks were performed with each set of samples to check for the presence of interfering peaks. Detection limits were determined by injecting decreasing concentrations of PAH standards. A signal-to-noise ratio of. 3:1 was used as the criteria for the limit of detection. PAH detection limits were between $0.03 \mathrm{ng} / \mathrm{g}$ (benzo(k)fluoranthene) and $0.15 \mathrm{ng} / \mathrm{g}$ (indeno(1,2,3cd)pyrene) and the detection limits of the other compounds were between 0.01 $\mathrm{ng} / \mathrm{g}$ and $0.03 \mathrm{ng} / \mathrm{g}$.

\section{Organic carbon determination}

Total organic carbon (TOC) was determined according to the method of Gaudette et al. [8]. Ten milliliters of $1 \mathrm{~N} \mathrm{~K}_{2} \mathrm{Cr}_{2} \mathrm{O}_{7}$ solution was added to $0.5 \mathrm{~g}$ of dry soil; then $20 \mathrm{ml}$ of concentrated sulfuric acid was added and the mixture was gently shaken, and left to digest for $30 \mathrm{~min}$. The solution was then diluted to $200 \mathrm{ml}$ with distilled water, and $10 \mathrm{ml}$ of phosphoric acid and $0.2 \mathrm{~g}$ of NaF was added. Finally, the solution was cooled and titrated with anhydrous ferrous sulfate ammonium.

\section{Statistical analysis}

Statistical analysis was performed using standardized data through a statical software package (STATISTICA. Statsoft Inc., 1997). For comparison of median and principal component \& classification analisis (PCCA), values lower of limit of detection (LOD) and limit of quantification (LOQ) were estimated by half of LOD and LOQ, respectively.

\section{RESULTS AND DISCUSSION}

PAHs levels in each site are reported in table 1. Total PAHs for Lleulleu were 190 and $648 \mathrm{ng} \mathrm{g}^{-1} \mathrm{TOC}$; and for Cholguan were 580 and $3396 \mathrm{ng} \mathrm{g}^{-1}$ $\mathrm{dw}$, respectively. In both sampling campaigns the levels were higher at the Cholguan site $(\mathrm{p}<0.001)$ (table 1). In Cholguan site the observed levels were related to an anthropogenic source, due to the presence of a wood pallet mill using boilers feed with wood residues. Lleulleu site corresponded to typical background levels [5]. 
Table 1. Summary PAHs concentrations in surface forest soils in both sites and periods (ng $\left.\mathrm{g}^{-1} \mathrm{TOC}\right)$.

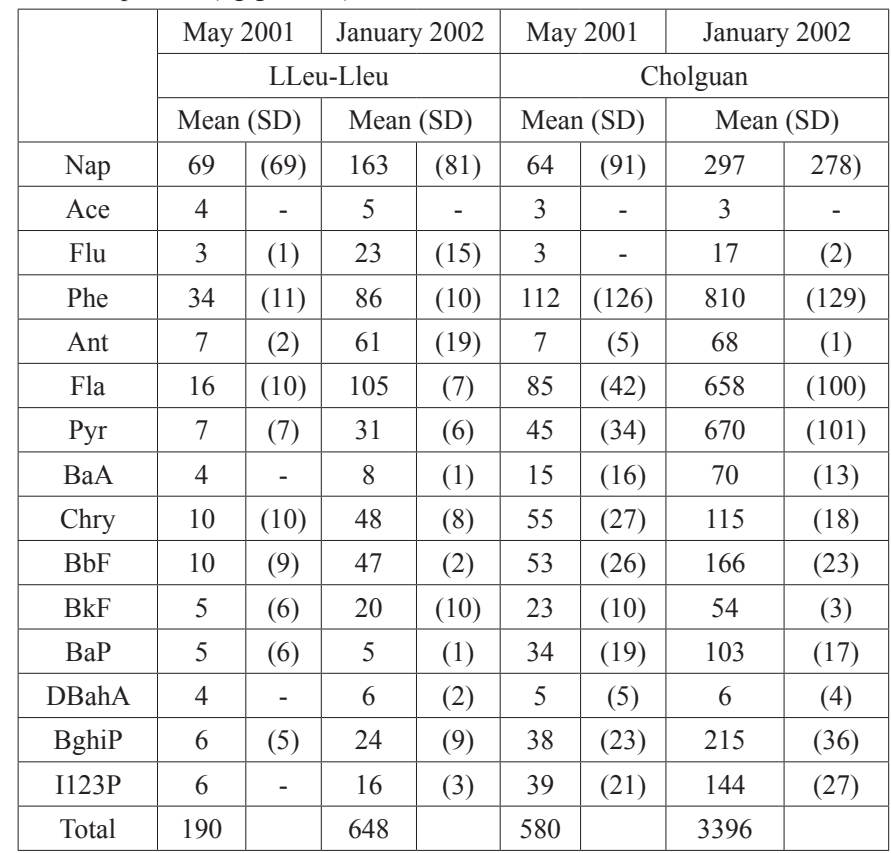

Percentage of TOC in each period of sampling showed values similar without significant differences with a mean of 3.9 and $5.9 \%$ for Lleulleu and Cholguan sites, respectively.

For each site, the PAHs fingerprint in soils were almost identical during the two sampled periods, however differences could be observed between sites (figure 1), despite of differences in concentrations. This fact could be explained by the different sources contributing PAHs into the forest soils or the "wheatering process" typical of temperate zones, i.e., transformation during atmospheric transport [9]. Temporal change in the accumulation of PAH in soil from atmospheric sources has been observed for Cousins and Jones [10] and Tremolada et al [11], it seems that the sources contributing PAHs into the soil are the same. In rural zones it have been described annual cycles of PAHs in rain and in aerosol deposition, with maximum concentrations during the winter and minimal concentrations during the summer $[11,12]$. We hypothesize that in our study zone, changes in concentrations between May of 2001 and January 2002, may be due to an increment in the local emissions from the same sources. Increasing concentrations at Lleulleu site may be due to the increased incidence of forest fires in the summer months [13] and in the case of Cholguan may be attributed to a local source such as a mill industry located near the study site.
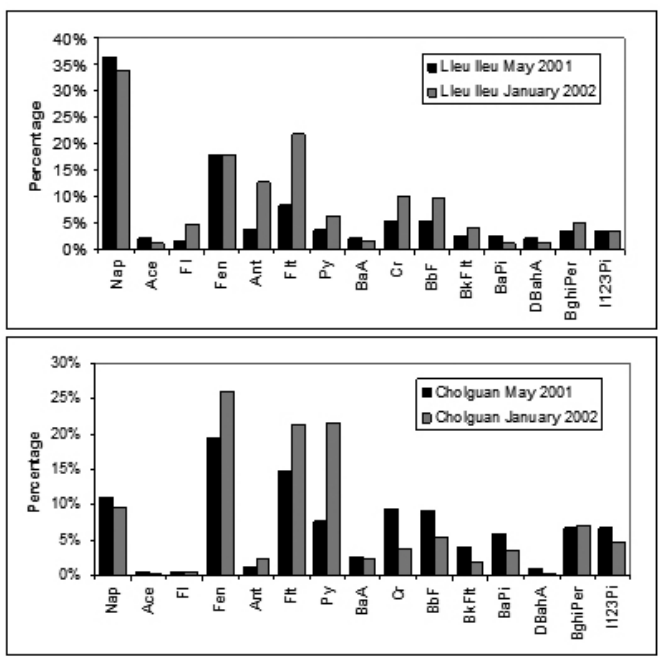

Figure 1. Fingerprints of LLeulleu and Cholguan in both sampling campaigns.
A principal component and classification analysis (PCCA) was used to analyze the possible origin of PAHs using fingerprints of vegetation, wood and coke combustion process $[14,15]$ and data of soil from a contaminated zone (garden, highways and home garden) [16]. Results are shown in the figure 2, the two first principal components explained $92 \%$ of the variability with values of $72 \%$ for PC1 and $20 \%$ for PC2. There is a simple structure of two groups defined for the fingerprints of sources, where the sites from Cholguan and Lleulleu are related with sources of wood and coke combustion, respectively.

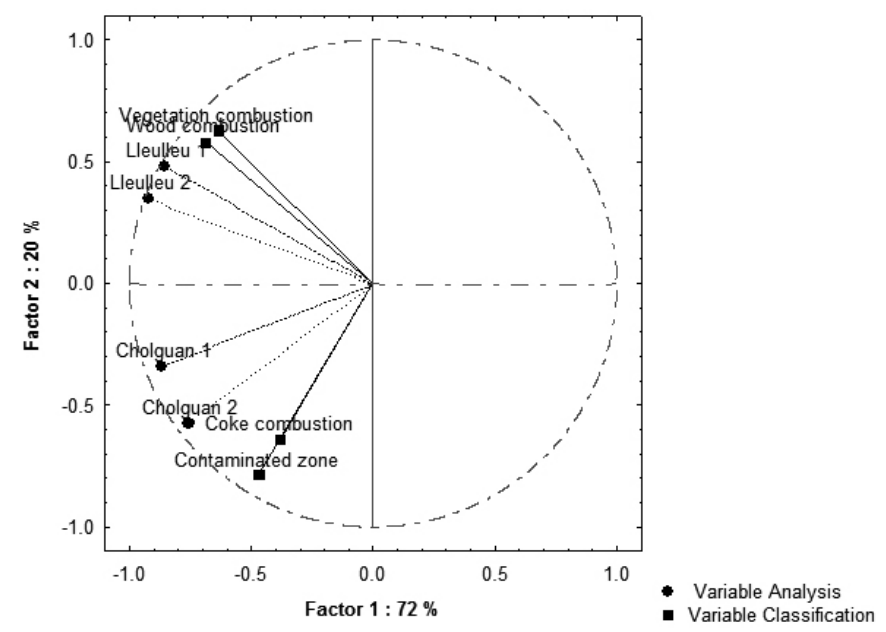

Figure 2. $\mathrm{PCA} / \mathrm{CA}$ of fingerprints $\mathrm{PAHs}$

\section{CONCLUSION}

In general these results suggest a temporal changes in the PAHs burden in the forest soils and the change in the intensity of source emissions. In both sites the observed seasonal changes may be due to local sources, in the coastal site (Lleulleu) attributed to wood combustion, and in the central valley zone attributed to coal/wood combustion. In is important to continue working in the characterization of fingerprints, for a better source apportionment of PAHs in Chile.

\section{ACKNOWLEDGEMENTS}

This study was supported by FONDECYT N 1080294 and CONICYTBMBF granted to Peter Popp (UFZ-Germany) and Ricardo Barra (EULAChile)

\section{REFERENCES}

[1] R. Barra, C. Castillo, J. P. M. Torres, Rev Environ Contam Toxicol, 191, 1-22 (2007).

[2] M. L. Diamond, D. A. Priemer, N. L. Law, Chemosphere, 44, 1655-1667 (2001).

[3] S. R. Wild, K. C. Jones, Environmental Pollution, 88, 91-108 (1995).

[4] M. Howsam, K. C. Jones, P. Ineson, Environmental Pollution, 113, 163$176(2001)$.

[5] R. Barra, P. Popp, R. Quiroz, C. Bauer, H. Cid, W. v. Tumpling, Chemosphere, 58, 905-915 (2005).

[6] M. Henriquez, J. Becerra, R. Barra, J. Rojas, J. Chil. Chem. Soc., 51, $938-$ 944 (2006).

[7] R. Quiroz, P. Popp, R. Urrutia, C. Bauer, A. Araneda, H.-C. Treutler, R. Barra, Science of The Total Environment, 349, 150-160 (2005).

[8] H. E. Gaudette, W. R. Flight, L. Toner, D. W. Folger, J. Sediment. Petrol., 44, 249-253 (1974).

[9] K. C. Jones, J. A. Stratford, P. Tidridge, K. S. Waterhouse, A. E. Johnston, Environmental Pollution, 56, 337-351 (1989).

[10] I. T. Cousins, K. C. Jones, Environmental Pollution, 102, 105-118 (1998).

[11] P. Tremolada, M. Parolini, A. Binelli, C. Ballabio, R. Comolli, A. Provini, Science of The Total Environment, 407, 4269-4277 (2009).

[12] G. Kiss, Z. Varga-Puchony, B. Tolnai, B. Varga, A. Gelencsér, Z. Krivácsy, J. Hlavay, Environmental Pollution, 114, 55-61 (2001).

[13] CONAF, Estadisticas historicas de incendios forestales en Chile, 2011. 
[14] B. M. Jenkins, A. D. Jones, S. Q. Turn, R. B. Williams, Environmental Science and Technology, 30, 2462-2469 (1996).

[15] R. C. Lao, R. S. Thomas, J. L. Monkman, Journal of Chromatography, Vol. 112, 681-700 (1975).
[16] W. Wilcke, W. Amelung, M. Krauss, C. Martius, A. Bandeira, M. Garcia, Organic Geochemistry, 34, 1405-1417 (2003). 